\title{
Post-slaughter Intervention Techniques to Ensure Tenderness of Beef Muscles for Korean Consumers
}

\author{
I. H. Hwang
}

Institute of Rare Earth for Biological Application, Chonbuk National University, Jeonju, 561-756, Korea

\author{
한국 소비자 쇠고기 연도 보증을 위한 도축후 도체 처리기술 \\ 황인호 \\ 전북대학교 희토생물응용연구소
}

요 약

\begin{abstract}
쇠고기 연도 조절에 대한 연구는 오랜 역사를 가지고 있으나, 균일한 쇠고기 맛에 대한 소비자들의 요구 증가로 응용적 연구가 가속화 되고 있다. 도축 후 근절길이와 단백질 분해가 연도에 큰 영향을 미친다는 사실은 잘 밝혀졌다. 전기자극은 맛 보증 프로그램을 위해서 여러 나라에서 산업적으로 이 용되고 있다. 전기자극이 연도를 향상(또는 질겨짐 감소)시키는 기전은 모두 밝혀지지 않았으나, 이 처리가 저온 단축을 막고 사후 강직을 단축시켜 단백질 분해를 증가시킨다는 결과는 명확해 보인다. 한편 Tenderstretch는 사후 강직기 동안 근섬유와 결체 조직에 장력을 가하여 고기의 질겨짐을 줄이는 작용을 하는 것으로 보인다. 선행 연구들은 도축 후 전기자극과 Tenderstretch 처리가 지방이 많은 가 축과 냉각 온도가 느린 조건에서도 연도를 향상 시킨다는 사실들을 증명하였다. 최근 연구에 의하면 한국 소비자들도 연도가 쇠고기 맛을 결정하는데 중요한 요인이며, 국내 연구결과에 의하면 도축 후 전기자극 또는 tenderstretch 처리가 한우의 연도 및 육색을 증가시키는 것으로 나타났다. 특히 이 기 법들은 도체의 크기 및 지방 침착도와 도축 후 냉각속도 조절이 어려운 국내 축산업 조건에서 연도 의 균일성 및 개선을 보장할 수 있는 중요한 기법으로 판단되나, 국내 산업체에서는 이용되지 않고 있다. 이 논문은 이러한 기법에 대한 현재의 이론과 국내 쇠고기 산업에 주는 의미를 서술했다.
\end{abstract}

(Key words : Beef, Tenderness, Electrical stimulation, Tenderstretch)

\section{INTRODUCTION}

Problem in consistency of eating quality is largely related to meats than other foods primarily due to greater variations in pre-slaughter animal status and its biochemical changes during the conversion from muscle to meats. Tenderness and flavor are attributed by consumers as the most significant elements of eating quality, while color is the most important attribute at the point of purchase (Becker et al., 1998). Although numerous research groups have attempted to manipulate eating quality, it still remains an elusive goal to be fulfilled in meat science.

Intrinsic and environmental factors affecting meat tenderness include breed, sex, growth pathway, preslaughter handling and post-slaughter interventions such as tenderstretch and electrical stimulation (Thompson, 2002). Improvement of tenderness and consistency have been challenged from a

Corresponding author : InHo Hwang, Institute of Rare Earth for Biological Application, Chonbuk National University, Jeonju, 561-756, Korea

Tel : +82-063-270-2605, Fax : +82-063-270-2605, E-mail : inho.hwang@chonbuk.ac.kr 
number of aspects including genetic (Miller, 1997) and nutritional manipulation (Eggen and Hocquette, 2004; Peter and Purslow, 2005). Both muscle fiber and connective tissue have been considered responsible for toughness of meats. As connective tissue being responsible for a relatively fixed background toughness (Wheeler and Koohmaraie, 1994), myofibril component has received much attention during postmortem operations through the ways of reducing muscle shortening and optimizing enzymatic proteolysis (Devine et al., 1999; Sorheim and Hildrum, 2002; Hwang et al., 2003).

The postmortem intervention techniques include manipulation of chilling regime, rate of glycolysis, tenderstretch, tendercut, method of ageing, injection of ions or organic acids and high pressure treatments. To ensure the least muscle shortening and optimum postmortem proteolytic tenderization, electrical stimulation and alternation in suspension methods are mostly useful measurements. In particular, when control of carcass size, fatness and/or chilling regimes is difficult under a particular industrial conditions such as Korean beef industry the techniques are likely more useful. Beef tenderness is likely not an issue of priority for Korean beef industry, as thin sliced beef cooking style is prevalent and dominant among Korean consumers (Cho et al., 1999). Recently, Park et al. (2006) showed that when longissimus muscle was cooked by Korean BBQ style (ca. $5 \mathrm{~mm}$ thin slice), relative importance for judging eating quality for tenderness, juiciness and flavor were $0.42,0.31$ and 0.27 , respectively. The study concluded that the beef tenderness was the most important issue to be considered. Electrical stimulation and tenderstretch techniques have been used by a number of countries to underpin carcass quality assurance schemes focused on eating quality (Thompson, 2002; Sorheim and Hildrum, 2002). The mechanism(s) by which the postmortem interventions improve tenderness (or prevent toughness) has not been fully elucidated. However, it is evident that electrical stimulation accelerates the development of rigor mortis so that ageing commences at higher temperatures, while tendersretch appears to prevent meat toughness via placing tension of the myofibrils and connective matrix during rigor development. Combination of both techniques is not always cumulative, but the effectiveness depends on the industrial situation. The manuscript attempts to highlight the current knowledge about understanding the cause of meat toughness, effects of electrical stimulation and tenderstretch on meat tenderness and finally its implications for Korean beef industry aiming primarily towards the assurance of beef tenderness.

\section{CAUSES OF MEAT TOUGHNESS}

Myofibril-related meat toughness is a time dependant variable from the time of slaughter to cooking process. Meat toughening that occurs during the first $24 \mathrm{~h}$ after slaughter was most likely due to sarcomere shortening (Koohmaraie et al., 1996) as a consequencial confliction between improving meat hygiene and processing efficiency.

Muscle contraction is dependable on the temperature at the time rigor occurs either below $10^{\circ} \mathrm{C}$ with $\mathrm{pH}$ higher than 6.2 , or higher than $30^{\circ} \mathrm{C}$ with $\mathrm{pH}$ lower than 6.2 (Bendall, 1976). In general terms, myofibril-related toughness is related to both (or either) the binding strength of myosin heads to actin in the rigor complex and toughness increases in direct proportion to the number of such cross-bridges (Goll et al., 1995), and (or) extent of overlapping between the actin and myosin filaments (Locker and Hagyard, 1963), while Hopkins and Thompson (2001) failed to demonstrate the relationship between strength of myosin/actin complex and tenderness. Furthermore, relationship between sarcomere length and tenderness shows relatively high coefficient 
for normal and fast chilling muscles (Wheeler and Koohmaraie, 1999; Hwang et al., 2004). Bouton et al. (1973) found significantly shorter sarcomere lengths in the $M$. semimembranosus, M. gluteus medius, $M$. biceps femoris, and $M$. longissimus dorsi muscles, as well as significantly tougher $M$. adductor and $M$. vastus lateralis muscles conditioned at $0-1{ }^{\circ} \mathrm{C}$ compared to those conditioned at $15-16^{\circ} \mathrm{C}$. They also found strong relationships between Warner-Bratzler shear force values and sarcomere lengths when sarcomeres were shorter than $2.0 \mu \mathrm{m}$. Previous studies (Locker and Hagyard, 1963; Devine et al., 1999) have demonstrated that muscles that enter rigor mortis at $12-15^{\circ} \mathrm{C}$ resulted in the most tender texture.

On the other hand, sarcomere length is not always a good indicator of tenderness for slowly chilled muscles (Smulders et al., 1990; Hwang et al., 2004). The former study demonstrated that when beef longissimus and semimembranosus muscles entered rigor mortis and aged upto 24 hours postmortem (sarcomeres: ca. $1.5 \mu \mathrm{m}$ ) the meats had a similar shear force with ordinary meats (sarcomeres: ca. $1.8 \mu \mathrm{m}$ ). The studies suggested that proteolytic activity by endogenous proteolytic enzymes have a significant role in determining meat tenderness. It has been well documented that the rate and extent of myofibril-related tenderization depends on the activation of endogenous proteolytic enzymes, particularly u-calpain, but it will not be discussed in details (see recent review Koohmaraie and Geesink, 2006).

The combination of $\mathrm{pH}$-temperature-time differs between muscles and even within a muscle. The fact indicates that all muscles are not affected to the same degree by $\mathrm{pH} /$ temperature window during rigor development (Hannula and Puolanne, 2004). The cause of toughening and tenderization during the first $24 \mathrm{~h}$ has been debated. On the other hand, a previous study (Wheeler and Koohmaraie, 1994) demonstrated that soon after slaughter the lamb longissimus muscle showed an intermediate shear force values (approximately $5 \mathrm{~kg}$ ), while process of rigor development induced toughness with the maximum toughness at $12-24 \mathrm{~h}$ postmortem. The rigor toughness was then followed by by post-mortem tenderization as a function of enzymatic degradation of myofibriallar, cytoskeletal and associated proteins. It was gathered from previous studies that the dramatic changes in tenderness concurred with changes in sarcomere length even under moderate chilling conditions. The pilot study suggests that minimizing physical shortening during rigor development and maximizing afterward is the best practice for postslaughter intervention to ensure the tender meat. As the muscle shortening and postmortem proteolytic activity are largely affected by tension placed on individual muscle and biological interaction between $\mathrm{pH}$ and temperature, identification of appropriate suspension methods and electrical stimulation parameters are priority in this regard.

\section{ELECTRICAL STIMULATION}

Application of electrical stimulation to the whole carcass does not affect all muscle equally (Olsson et al., 1994), due to the heterogeneous muscles with different glycolytic characteristics and geological difference (O’Halloran et al., 1997). However, the treatment improves tenderness for most muscles such as $M$. semimembranosus, $M$. semitendinosus, $M$. biceps femoris, $M$. vastus lateralis, M. gluteus medius, M. longissimus dorsi lumborum, and M. triceps brachii (Stolowski et al., 2006) and reduce variation in tenderness between animals (Strydom et al., 2005). The rate of temperature decline in carcass is affected by various factors including carcass factors (size, shape and fatness) and chilling factors (temperature, relative humidity and pattern of the air flow) (Smulders et al., 1992). For the given muscle under a fixed chilling condition, optimum $\mathrm{pH}$-temperature combinations for tender meat (Devine et al., 
1999, Hwang and Thompson, 2001) could be achieved by appropriate strength of electrical stimulation.

Classic view of the effect of electrical stimulation on production of tender meat was attributed to the prevention of cold shortening by using up energy before the rigor onset, acceleration of enzymatic proteolysis and (or) physical impact, while detailed mechanisms have been controversial (Hwang et al., 2003 for review). More recently, White et al. (2006) reported that when hot-boned beef muscles were electrically stimulated by a low voltage system, improved tenderness was not related to proteolysis, but to physical disorganization. The detailed mechanisms have been an important issue from industrial viewpoint as the effectiveness and use of electrical stimulation under relative slow chilling condition have been questioned (Thompson, 2002). In this regard, a number of studies demonstrated that cold shortening is not a concern for highly fattened cattle such as long grain-fed Hanwoo (Hwang and Park, 2002) though stimulation benefits were still valuable. The authors did not statistically compare the results as only six animals were involved in the study, but the data showed that low voltage stimulation increased approximately $3 \mathrm{~kg}$ of WB-shear force and 5 points of redness at 24 hours postmortem (Table 1).

The answer to the question was found to be apparent with a series of studies (Devine et al., 2002, 2006). The former study demonstrated that when electrically stimulated lamb entered rigor either at $18^{\circ} \mathrm{C}$ or $35^{\circ} \mathrm{C}$, the muscles treated at 18 ${ }^{\circ} \mathrm{C}$ showed a higher rate of tenderization with the same WB-shear force at the completion of rigor (eg. zero ageing time). The study suggested that rigor temperature is a significant factor even for electrically stimulated carcass. This was further evident by the latter study (i.e., Devine et al., 2006), who demonstrated that electrical stimulation improved lamb longissimus tenderness when excisedwrapped muscles were placed at $15^{\circ} \mathrm{C}$ for both electrically stimulated and non-stimulated muscles, with significantly tender meat at the onset of rigor mortis for electrically stimulated meat. Although the time of rigor mortis is closely related to commencement of ageing (Devine and Graafhuis, 1994), some ageing takes place in some muscle fibers during the rigor development (Watanabe et al., 1996). Taken the studies it appears that early commencement of ageing process for muscle fibres that enter rigor early at near physical carcass temperature, possible ultrastructural changes and avoidance of significant autolysis of calpains may all interact to result in early tenderisation to a greater extent for electrically stimulated than for non-stimulated muscles. Apart from the electrical stimulation effect on prevention of cold shortening and optimum proteolysis, reducing shortening (or increasing sarcomere length) could be a multi-dimensional way of improving meat tenderness, the following section will further highlight alternation of suspension method on the management of meat tenderness.

Table 1. Least square mean and standard deviation of objective meat quality of Hanwoo longissimus muscle at 1 day postmortem $(n=6)$

\begin{tabular}{ccccc}
\hline & WB-shear force $(\mathrm{kg})$ & Cooking loss $(\%)$ & Hunter $L^{*}$ & Hunter $a^{*}$ \\
\hline \hline Control & $6.88 \pm 3.3$ & $25 \pm 1.3$ & $30.6 \pm 1.2$ & $13.5 \pm 1.4$ \\
ES $^{\mathrm{a}}$ & $3.93 \pm 1.2$ & $25.6 \pm 4.3$ & $33.7 \pm 3.6$ & $18.1 \pm 3.3$ \\
\hline
\end{tabular}

${ }^{a}$ Forty five volts $(50 \mathrm{~Hz}, 36$ pulse/sec) stimulation was applied immediately after bleeding by a nose/anal system for 2 bursts of 10 seconds. Cited from Hwang and Park (2002). 


\section{ALTERNATION OF SUSPENSION METHOD}

The research on muscle stretching or restraining techniques started in the late 1960s and early 1970s (Herring et al., 1965; Hostetler et al., 1972) and is now being renewed at the wake of increasing demand for tender meat. Recently, a number of countries, including Australia, Island, England, Swedish and Norway, have implemented the stretching method (Tarrant, 1998; Sorheim and Hildrum, 2002 Thompson, 2002). When applied to the carcass pre-rigor, pelvic hanging places tension on the major leg and loin muscles, which either minimizes shortening, or stretches the muscles with subsequent improvement in tenderness of hind and loin muscles in the carcass, with little effect on forequarter muscles (Hostetler et al., 1972; Bouton et al., 1973; Ferguson et al., 1999; Maher et al., 2004). Furthermore, tenderstretch reduced variability in $m$. semimembranosus of young bulls (Ahnström et al., 2006) and $m$. longissimus and $m$. semimembanosus of commercial heavy weights (Maher et al., 2004). However, in some minor muscles of the hindlimb and loin ( $\mathrm{mm}$. psoas major, iliacus, gluteus profundus, tensor fascia latae, gastronemius, and gracilis) tenderstetch allowed the muscles fibres to shorten. For the $\mathrm{mm}$. psoas major, iliacus, and gastronemius the decrease in sarcomere length in the tenderstretched sides was small, and any consequent decrease in palatability was not apparent (Hwang et al., 2002, Table 2).

The principle of suspending carcasses from the aitch-bone (pelvic bone) for improving tenderness in beef and lamb has been known to be related to its effect on myofibrils and connective matrix by minimizing shortening or stretching the muscle tissue (Bouton et al., 1973), while biological mechanisms are not clearly identified. On the other hand, studies reported that tenderstretch effect on actin/myosin overlap was not the prime reason for the tender meat (Hopkins and Thompson, 2001). The authors demonstrated that the energy required to dissociate the actomyosin complex in carcasses subjected a range of stretching treatment for pre-rigor lamb was similar. In addition, while calpastatin activity was affected by interaction between breed and muscle type (Stolowski et al., 2006) and genetic difference in tenderness between Brahman and composite carcasses was diminished by tenderstretch treatment (Burrow et al., 2006), the calpain system was not affected by tenderstretch treatment (O'Halloran et al., 1998). If the treatment does not affect endogenous proteolytic enzyme system and binding strength between actin and myosin, its physical effect could be a considerable factor. This was evidenced by a lamb study (Thompson et al., 2005) in that the effect of rigor temperature on tenderness for tenderstretched muscle was negligible.

When stretching is enforced before rigor mortis, the collagen fibers are partly unfolded and oriented more in the direction of the fires (Rowe, 1974) which could result in more collagen fibres for shearing perpendicular to the muscle fiber. Thus tenderstretched muscle requires a more higher shear force in raw muscle and when cooked at lower temperature. However, its influence on the resistance in shearing decreases, if collagen denatures at a high temperature (Eikelenboom et al., 1998). Tornberg (1996) proposed a model to explain the interaction between stretched muscle and cooking temperature on tenderness. She proposed that in the raw state stretched muscle was tougher due to a smaller viscous component in the muscle structure. On heating above $60^{\circ} \mathrm{C}$, because of the smaller extracellular space in 
Table 2. Predicted $\mathrm{MQ}^{\delta}$ scores as a function of hanging method (Hang) and different positions (Pos) within selected muscles from normally hung (AT) and tenderstretch sides hung by either the aitch bone (TS aitch), or the ligament (TS lig) after adjustment for side and a random animal effect

\begin{tabular}{|c|c|c|c|c|c|c|c|c|}
\hline & \multirow[t]{2}{*}{$\operatorname{Pos}^{\phi}$} & \multicolumn{3}{|c|}{ Hanging method } & \multirow[b]{2}{*}{ Av. SE } & \multicolumn{3}{|c|}{ Significant level } \\
\hline & & $\mathrm{AT}$ & TS aitch & TS Lig & & Hang & Pos & Hang $\times$ Pos \\
\hline \multirow{3}{*}{ Longissimus dorsi } & A & 54.8 & 60.0 & 59.2 & \multirow{3}{*}{2.6} & \multirow{3}{*}{0.0005} & \multirow{3}{*}{0.3175} & \multirow{3}{*}{0.033} \\
\hline & B & 54.8 & 56.8 & 53.3 & & & & \\
\hline & $\mathrm{C}$ & 49.6 & 48.4 & 56.1 & & & & \\
\hline \multirow{4}{*}{ Biceps femoris } & A & 60.1 & 69.5 & 60.2 & \multirow{4}{*}{2.5} & \multirow{4}{*}{0.0001} & \multirow{4}{*}{0.0001} & \multirow{4}{*}{0.6659} \\
\hline & B & 41.0 & 47.6 & 45.5 & & & & \\
\hline & $\mathrm{C}$ & 39.0 & 47.7 & 44.4 & & & & \\
\hline & $\mathrm{D}$ & 40.3 & 46.7 & 40.3 & & & & \\
\hline \multirow{3}{*}{ Semimembraneous } & A & 43.8 & 47.6 & 48.0 & \multirow{3}{*}{2.3} & \multirow{3}{*}{0.0006} & \multirow{3}{*}{0.8074} & \multirow{3}{*}{0.0207} \\
\hline & B & 45.8 & 48.6 & 47.9 & & & & \\
\hline & $\mathrm{C}$ & 38.8 & 54.1 & 46.7 & & & & \\
\hline \multirow{3}{*}{ Gluteus medius } & A & 54.1 & 60.6 & 62.0 & \multirow{3}{*}{2.52} & \multirow{3}{*}{0.0004} & \multirow{3}{*}{0.0524} & \multirow{3}{*}{0.6598} \\
\hline & B & 54.3 & 61.8 & 58.8 & & & & \\
\hline & $\mathrm{C}$ & 55.9 & 67.5 & 64.4 & & & & \\
\hline \multirow{2}{*}{ Vastus lateralis } & A & 40.1 & 51.2 & 43.3 & \multirow{2}{*}{2.92} & \multirow{2}{*}{0.0013} & \multirow{2}{*}{0.0595} & \multirow{2}{*}{0.6935} \\
\hline & B & 34.3 & 45.9 & 41.7 & & & & \\
\hline \multirow{2}{*}{ Psoas major } & A & 76.0 & 75.2 & 64.9 & & & & \\
\hline & B & 75.3 & 76.3 & 69.3 & 2.7 & & & \\
\hline Cemitandino & A & 36.7 & 36.6 & 36.0 & 00 & C & 0001 & 0014 \\
\hline 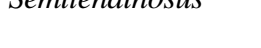 & B & 40.8 & 46.3 & 43.2 & 2.0 & $0.4 \angle 0$ & 0.001 & 0.0014 \\
\hline Abductor & & 49.8 & 58.3 & 55.5 & 2.50 & 0.0996 & & \\
\hline Gracilis & & 55.7 & 59.6 & 55.3 & 2.10 & 0.1460 & & \\
\hline Iliacus & & 72.6 & 69.7 & 61.6 & 3.50 & 0.0876 & & \\
\hline Gluteus profundus & & 63.6 & 62.7 & 58.9 & 2.71 & 0.3941 & & \\
\hline Gastrocinemius & & 52.7 & 47.2 & 41.0 & 2.90 & 0.0167 & & \\
\hline Vastus medialis & & 59.5 & 66.7 & 63.0 & 2.10 & 0.0817 & & \\
\hline Vastus intermedius & & 54.6 & 62.4 & 53.6 & 2.20 & 0.0206 & & \\
\hline Rectus femoris & & 48.3 & 56.4 & 53.0 & 1.90 & 0.0348 & & \\
\hline Tensor fascia latae & & 59.9 & 51.8 & 47.8 & 2.60 & 0.0187 & & \\
\hline
\end{tabular}

${ }^{\delta}$ MQ4 $=0.4 \times$ tenderness $+0.1 \times$ juiciness $+0.2 \times$ flavour $+0.3 \times$ overall acceptability.

$\$$ Cranial to caudal, proximal to distal positions within the muscles were coded as A, B, C and D, Cited from Hwang et al. (2002). 
stretched muscle there was less room for connective tissue to contract without being restricted by the myofibrillar mass. This resulted in a more tender muscle for the tenderstretched muscle. This provided an explaination that effect of tenderstretch on meat tenderness is a consequence of interaction between muscle and cooking temperature particularly for high connective tissue levels.

In relation to physical tension on muscles, which prevents muscles from shortening during rigor development, Bouton et al. (1973) noted that tenderstretch treatment can be used under fast rates of chilling without causing undue toughening. Similarly tenderstretch has been shown to be more effective in cold shortening conditions where electrical stimulation was unavailable (Sorheim et al., 2001). If the tenderstretch treatment improves tenderness by solely preventing cold shortening, the treatment of fattened carcass under mild chilling conditions will not be required. On the other hand, even in the mild chilling conditions where tenderstretched carcasses were placed at 10 ${ }^{\circ} \mathrm{C}$ for 10 hours and replaced at $2^{\circ} \mathrm{C}$ until $24 \mathrm{~h}$ postmortem, variation in eating quality for $m$. longissimus and $m$. semimembanosus of commercial heavy weight was significantly reduced (Maher et al., 2004).

To the best knowledge, there is no available information regarding the effect of interaction between tenderstretch and electrical stimulation on meat tenderness under various stimulation and chilling conditions and remains a question whether additive effect of tenderstrech after electrical stimulation exists. However, Ferguson et al. (1999) concluded that tenderstretch and electrical stimulation appeared to a degree additive in their impact on palatability of hindquarter muscles. Given the identified mechanisms of electrical stimulation and tenderstretch on improvement of tenderness, to ensure eating quality a multi-way postmortem intervention by application of electrical stimulation and tenderstretch is likely to benefit tenderness and this area requires further study.

\section{IMPLICATION FOR KOREAN BEEF INDUSTRY}

Assurance of satisfactory eating quality is a multi-disciplinary subject from genetics to meat processing. Korean consumers prefer high marbled beef (Cho et al., 1999) as it was found that the meat is juicier with favorable flavor (Park et al., 2000). For the same reason, beef grading scheme is largely relied on marbling score, and production strategy of beef farmers is targeted on high marbled beef (Lee et al., 2003; Moon et al., 2003; Park et al., 2003; Lee et al., 2004). On the other hand, a recent study (Park et al., 2006) showed that when Hanwoo longissimus muscle was cooked by Korean BBQ style (ca. $5 \mathrm{~mm}$ thin slice), relative importance for judging eating quality for tenderness, juiciness and flavor were $0.42, \quad 0.31$ and 0.27 , respectively. The result indicated that tenderness is the most important issue for Korean consumers when they consume cooked beef.

As previously discussed, from the standpoint of beef tenderness, apart from intrinsic toughness, the critical time postmortem is physical and biological status of individual muscle during rigor development (Dransfield et al., 1999) and tenderstretch and electrical stimulation are the most feasible measurements for ensuring eating quality. The techniques are particularly the most useful where control of carcass size, fatness and/or chilling regimes are uneasy such as prevalent in Korean beef industry (Hwang et al., 2003; Sorheim and Hildrum, 2002). However, the 
Table 3. Least square mean, $F$ ratio and significance level for the effect of suspension methods on sensory tenderness of Hanwoo steers.

\begin{tabular}{lccccc}
\hline & \multicolumn{2}{c}{ Suspension method } & & \\
\cline { 2 - 3 } & Achilles tendon & Tenderstretch & & Av. SE & F ratio \\
\hline \hline m. longissimus & $65.1^{\text {a }}$ & 74.3 & & 1.45 & $51.7^{* * *}$ \\
m. triceps brachii & 56.7 & 54.9 & & 1.44 & 1.4 \\
m. semimembranosus & 45.2 & 60.5 & & 1.36 & $75.1^{* * *}$ \\
\hline
\end{tabular}

${ }^{a} 0$ : very tough, very dry, dislike extremely, dislike extremely; 100: very tender, very juicy, like extremely. Cited from Park et al. (2006).

treatment has not been adopted by industry and the reason is unknown. Park et al. (2006) demonstrated tenderstretch technique greatly improved eating quality of $\mathrm{mm}$. longissimus and semimembranosus for Hanwoo steers (Table 3) and further study is under way (personal communication). Beef muscles are intrinsically variable in eating quality (Belew et al., 2003), while electrical stimulation and tenderstretch have provided ample of evidence for improving its consistency. Korean beef farmers and consumers would expect the post-slaughter interventions be placed in slaughterhouse sooner or later.

\section{CONCLUSION}

Meat tenderness for Korean consumers has become an obvious attribute to determine eating quality. Both electrical stimulation and tenderstretch showed to improve tenderness and its consistency of Hanwoo beef. Korean beef industry, in particular where control of carcass size, fatness and/or chilling regimes are difficult, the postslaughter intervention techniques such as electrical stimulation and tenderstretch could become the most feasible measurement to ensure eating quality.

\section{ABSTRACT}

Management to improve beef tenderness is always been a historical idea, but during the recent past it has become an issue of prime importance to the meat scientists and the industries as well. Variation in tenderness is the prime explanation for consumer's dissatisfaction for the concern meat. It has been well documented that both postmortem proteolysis and sarcomere length have significant effect on meat tenderness and its consistency. Electrical stimulation and tenderstretch techniques have been used by a number of countries to underpin carcass quality assurance schemes focused on eating quality. The mechanism(s) by which the postmortem interventions improve tenderness (or prevent toughness) has not been fully elucidated. However, it is evident that electrical stimulation accelerates the development of rigor mortis so that prevention of cold shortening is possible and ageing commences at higher temperatures. On the other hand, tendersretch appears to prevent meat toughness via placing tension of the myofibrils and connective matrix during rigor development. Previous findings indicated that electrical stimulation and tenderstretch improved beef tenderness even for fattened cattle under moderate chilling conditions. Recent studies demonstrate beef tenderness to be 
one of the most important factors determining satisfaction levels of Korean beef consumers. There are number of studies which reported that electrical stimulation and tenderstretch techniques improved Hanwoo tenderness and color. It is believed that the techniques are mostly useful wherein controls of carcass size, fatness and/or chilling regimes are not easy such as Korean beef industry. However, Korean beef industry is one such area where postmortem intervention techniques have not been adopted so far. Taking into consideration of the Korean beef industry, wherein carcass size and fatness varies the post-slaughter intervention technique could be the most feasible measurement to ensure eating quality. The manuscript attempts to highlight the current knowledge aiming primarily towards the assurance of beef tenderness.

(Key words : Beef, Tenderness, Electrical stimulation, Tenderstretch)

\section{ACKNOWLEDGEMENT}

This paper was supported (in part) by research funds of Chonbuk National University in 2005

\section{REFERENCES}

1. Ahnström, M. L., Enfält, A. C., Hansson, I. and Lundström, K. 2006. Pelvic suspension improves quality characteristics in $\mathrm{M}$. semimembranosus from Swedish dual purpose young bulls. Meat Sci. 72: 555-559.

2. Becker, T., Benner, E. and Glitsch, K. 1998. Report on consumer behaviour towards meat in Germany, Ireland, Italy, Spain, Sweden and The United Kingdom, Department of Agricultural Policy and Agricultural Economics, University of Hohenheim, Germany.

3. Belew, J. B., Brooks, J. C., McKenna, D. R. and
Savell, J. W. 2003. Warner-Bratzler shear evaluations of 40 bovine muscles. Meat Sci. 64:-507-512.

4. Bendall, J. R. 1976. Electrical stimulation of rabbit and lamb carcasses. J. Sci. Food and Agri. 27:819-826.

5. Bouton, P. B., Harris, P. V., Shorthose, R. and Baxter, R. I. 1973. A comparison of the effects of aging, conditioning and skeletal restraint on the tenderness of mutton. J. Food Sci. 38:932-937.

6. Burrow, H. M., Johnston, D. J., Thompson, J. M., Reverter, A., Barwick, S. A. and Perry, D. 2006. Conference proceedings "The genetics of carcass and beef quality: take homes messages from the Beef CRC. Australian Beef-the leader. The impact of science on the beef incustry." Armidale, NSW, Australia. Pp 69-78.

7. Cho, S. H., Lee, J. M., Kim, J. H., Park, B. Y., Yoo, Y. M. and Kim, Y. K. 1999 Survey of consumer perception and demand on beef market. Kor. J. Food Sci. Ani. Resour. 19:352-360.

8. Devine, C. E., Lowe, T. E., Wells, R. W., Edwards, N. J., Hocking Edwards J. E., Starbuck, T. J. and Speck, P. A. 2006. Pre-slaughter stress arising from on-farm handling and its interactions with electrical stimulation on tenderness of lambs. Meat Sci. 73:304-312.

9. Devine, C. E., Payne, S. R., Peachey, B. M., Lowe, T. E., Ingram, J. R. and Cook, C. J. 2002. High and low rigor temperature effects on sheep meat tenderness and ageing. Meat Sci. 60:141-146.

10. Devine, C. E., Wahlgren, N. M. and Tornberg, E. 1999. Effect of rigor temperature on muscle shortening and tenderization of restrained and unrestrained beef longissimus thoracicus et lumborum. Meat Sci. 51:61-72.

11. Devine, C. E. and Graafhuis, A. E. 1994. The basal tenderness of unaged lamb. Meat Sci. 39: 285-291.

12. Dransfield, E. 1999. Meat tenderness - The $\mu$-calpain 
hypothesis. In Proceedings 45th International Congress of Meat Science and Technology, (pp. 220-228), Yokohama, Japan.

13. Eggen, A. and Hocquette, J. F. 2004. Genomic approaches to economic trait loci and tissue expression profiling: application to muscle biochemistry and beef quality. Meat Sci. 66:1-9.

14. Eikelenboom, G., Barnier, V. M. H., HovingBolink, A. H., Smulders, F. J. M. and Culioli, J. 1998. Effect of pelvic suspension and cooking temperature on the tenderness of electrically stimulated and aged beef, assessed with shear and compression tests. Meat Sci. 49:89-99.

15. Ferguson, D., Thompson, J. and Polkinghorne, R. 1999. Meat Standards Australia, A 'PACCP' based beef grading scheme for consumers. 3) PACCP requirements which apply to carcass processing. 45th International Congress of Meat Science and Technology, Yokohama, Japan, 45, 18-19.

16. Goll, D. E., Geesink, G. H., Taylor, R. G. and Thompson, V. F. 1995. Does proteolysis cause all postmortem tenderization or are changes in the actin/myosin interaction involved. In Proceedings of the 41st International Meat Science and Technology Congress (pp. 537-544), San Antonio, TX.

17. Hannula, T. and Puolanne, E. 2004. The effect of cooling rate on beef tenderness: The significance of $\mathrm{pH}$ at $7^{\circ} \mathrm{C}$. Meat Sci. 67:403-408.

18. Herring, H. K., Cassens, R. G. and Briskey, E. J. 1965. Further studies on bovine muscle tendeness as influenced by carcass position, sarcomere length, and fibre diameter. J. Food Sci. 30:10491054.

19. Hopkins, D. L. and Thompson, J. M. 2001. The relationship between tenderness, proteolysis, muscle contraction and dissociation of actomyosin. Meat Sci. 57:1-12.

20. Hostetler, R. L., Link, B. A., Landmann, W. A. and Fitzhugh, H. A. Jr. 1972. Effect of carcass suspension on sarcomere length and shear force of some major bovine muscles. J. Food Sci. 37: 132-135.

21. Hwang, I. H. and Park, B. Y. 2002. The mechanisms by which electrical stimulation affect meat tenderness. Korean J. Food Sci. Ani. Resour. 22:234-239.

22. Hwang, I. H. and Thompson, J. M. 2001. The interaction between $\mathrm{pH}$ and temperature decline early postmortem on the calpain system and objective tenderness in electrically stimulated beef longissimus dorsi muscle. Meat Sci. 58:167-174.

23. Hwang, I. H., Devine, C. E. and Hopkins, D. L. 2003. The biochemical and physical effects of electrical stimulation on beef and sheep meat tenderness -a review. Meat Sci. 65:677-691.

24. Hwang, I. H., Gee, A., Polkinghorne, R. and Thompson, J. 2002. The effect of different pelvic hanging techniques on meat quality in beef. 48th International congress of Meat Science and Technology. Rome, Italy. 220-221.

25. Hwang, I. H., Park, B. Y., Cho, S. H. and Lee, J. M. 2004. Cause of muscle shortening, proteolysis and WB-shear force in beef longissimus and semitendinosus. Meat Sci. 68:497-505.

26. Koohmaraie, M. and Geesink, G. R. 2006. Contribution of postmortem muscle biochemistry to the delivery of consistent meat quality with particular focus on the calpain system. Meat Sci. (In Press).

27. Lee, C. E., Park, N. K., Seong, P. N., Jin, S. H., Park, B. Y. and Kim, K. I. 2003 Effects of deletion of Ca supplement (limestone) on growth and beef quality in Hanwoo finishing steers. J. Ani. and Technol. (Kor.). 45:455-462.

28. Lee, K. C., Park, N. H., Jeong, S. S., Lee, S. S., Oh, Y. S., Baek, K. H., Jung, K. K. and Choi, C. B. 2004. Effects of castration and slaughtering ages on physico-chemical characteristics of Hanwoo $m$. longissimus dorsi. J. Ani. and Technol. (Kor.). 46: 165-172. 
29. Locker, R. H. and Hagyard, C. J. 1963. A cold shortening effect in beef muscle. J. Sci. Food and Agri. 14:787-793.

30. Maher, S. C., Mullen, A. R., Keane, M. G., Buckley, D. J., Kerry, J. P. and Moloney, A. P. 2004. Decreasing variation in the eating quality of beef through homogenous pre- and postslaughter management. Meat Sci. 67:33-43.

31. Miller, B. 1997. Proceedings 43rd International Congress on Meat Science Technology Auckland, Meat Quality Workshop. pp. 52-79.

32. Moon, S. S., Hwang, I. H., Jin, S. K., Lee, J. G., Joo, S. T. and Park, G. B. 2003. Carcass traits determining quality and yield grades of Hanwoo steers. Asian-Australasian. J. Anim. Sci. 16:1049-1054.

33. O'Halloran, G. R., Troy, D. J., Buckley, D. J. and Reville, W. J. 1997. The role of endogenous proteases in the tenderisation of fast glycolysing muscle. Meat Sci. 47:187-210.

34. O'Halloran, J. M., Ferguson, D. M., Perry, D. and Egan, A. E. 1998. Mechanism of tenderness improvement in tenderstretched beef carcasses. 44th International Congress of Meat Science and Technology, Barcelona Spain, 712-713.

35. Olsson, U., Hertzman, C. and Tornberg, E. 1994. The influence of low temperature, type of muscle and electrical stimulation on the course of rigor mortis, ageing and tenderness of beef muscles. Meat Sci. 37:115-131.

36. Park, B. Y., Hwang, I. H., Cho, S. H., Yoo, Y. M., Kim, J. H., Lee, J. M., Polkinghorne, R. and Thompson, J. M. 2006. Beef palatability as assessed by Korean and Australian consumers: 3 . The effect of carcass suspension and cooking method on the palatability of three muscles. Meat Sci.. (in press).

37. Park, B. Y., Cho, S. H., Kim, J. H., Lee, W. S., Kim, Y. K., Ahn, C. N., Kim, J. M. and Yoon, S. G. 2003.
Carcass grading properties of imported beef cattle fed in Korea. J. Anim. and Technol. (Kor.). 45: 151-156.

38. Park, B. Y., Cho, S. H., Yoo, Y. M., Kim, J. H., Lee, J. M., Joung, S. K. and Kim, Y. K. 2000. Effect of intramuscular fat contents on the physicochemical properties of beef longissimus dorsi from Hanwoo. J. Ani. Sci. Tech. (Kor.). 42: 189-194.

39. Peter P. and Purslow, P. P. 2005. Intramuscular connective tissue and its role in meat quality. Meat Sci. 70:435-447.

40. Rowe, R.W. D. 1974. Collagen fibre arrangement in intramuscular connective tissue. Changes associated with muscle shortening and their possible relevance to raw meat toughness measurements. J. Food Techno. 9:501-508.

41. Smulders, F. J. M., Van Laack, R. L. J. M., Metrusty, S. C. and Jennissen, L. T. T. 1992. The effects of pelvic suspension and limb weighting on the sensory and processing properties of various porcine muscles, Proceedings of the 38th international congress of meat science and technology, Clermont-Ferrand, France, pp. 217-220.

42. Smulders, F. J. M., Marsh, B. B., Swartz, D. R., Russell, R. L. and Hoenecke, M. E. 1990. Beef tenderness and sarcomere length. Meat Sci. 28: 349-363.

43. Sorheim, O. and Hildrum, K. I. 2002. Muscle stretching techniques for improving meat tenderness. Trends in Food Sci. and Techno. 13:127-135.

44. Sørheim, O., Idland, J., Halvorsen, E. C., Frøystein, T., Lea, P. and Hildrum, K. I. 2001. Influence of beef carcass stretching and chilling rate on tenderness of $\mathrm{m}$. longissimus dorsi. Meat Sci. 57:79-85.

45. Stolowski, G. D., Baird, B. E., Miller, R. K., Savell, J. W., Sams, A .R., Taylor, J. F., Sanders, 
J. O. and Smith, S. B. 2006. Factors influencing the variation in tenderness of seven major beef muscles from three Angus and Brahman breed crosses. Meat Sci. 73:475-483.

46. Strydom, P. E., Frylinck, L. and Smith, M. F. 2005. Should electrical stimulation be applied when cold shortening is not a risk? Meat Sci. 70:733-742.

47. Thompson, J. 2002. Managing meat tenderness. Meat Sci. 62:295-308.

48. Thompson, J. M., Hopkins, D. L., D’Souza, D. N., Walker, P. J., Baud, S. and Pethick, D. W. 2005. The impact of processing on sensory and objective measurements of shep meat eating quality. Aust. J. Exp. Agri. 45:561-573.

49. Tarrant, P. V. 1998. Some recent advances and future priorities in research for the meat industry. Meat Sci. 49:S1-S16.
50. Tornberg, E. 1996. Biophysical aspects of meat tenderness. Meat Sci. 43:S175-S191.

51. Watanabe, A., Daly, C. C. and Devine, C. E. 1996. The effects of the ultimate $\mathrm{pH}$ of meat on tenderness changes during ageing. Meat Sci. 42:67-78.

52. Wheeler, T. L. and Koohmaraie, M. 1994. Prerigor and Postrigor Changes in Tenderness of Ovine Longissimus Muscle. J. Anim. Sci. 72:1232-1238.

53. Wheeler, T. D. and Koomaraie, M. 1999. The extent of proteolysis is independent of sarcomere length in lamb longissimus and psoas major. J. Anim. Sci. 77:2444-2451.

54. White, A., O’Sullivan, A., Tory, D. J. and O’Neill, E. E. 2006. Effects of electrical stimulation, chilling temperature and hot-boning on the tenderness of bovine muscles. Meat Sci. 73:196-203.

(접수일자 : 2006. 7. 10. / 채택일자 : 2006. 12. 4.) 